\title{
Sağlık İletişimi ve Sosyal Medya: Sivil Toplum Kuruluşlarının Twitter Kullanımı Üzerine Bir Değerlendirme ${ }^{a}$
}

\author{
Esra Vona Kurt ${ }^{\mathrm{b}}$
}

\section{Özet}

Sağlık iletişimi temelde bireyin ve toplumun sağlığını koruyacak, geliştirecek ve iyileştirecek bilgi ve enformasyonla sağllğın geliştirilmesini hedefleyen iletişim faaliyetlerine dayanmaktadır. İletişim teknolojilerindeki gelişmeler sağlık alanıyla ilgili bilgilerin geniş kitlelerle buluşmasında yeni bir dönemi başlatmıştır. Geleneksel kitle iletişim araçlarına göre daha fazla bilgi paylaşmanın bir yolunu sunan yeni iletişim teknolojileri, hızı, gönderilen mesajın biçimi, etkileşimli iletişim olanağı sunması ve bireysel kontrolün kullanıcıda olduğu bir teknolojiye işaret etmektedir. Çalışma, sağlık alanında faaliyet gösteren ve temel görevleri bireylerin, toplumun sağlığını geliştirmeyi hedefleyen sivil toplum örgütlerinin Twitter'ı nasıl kullandıklarını ortaya koymayı amaçlamaktadır. Araştırmada Türk Kanser Derneği, Türk Kalp Vakfı ve Türk Diyabet Cemiyeti'nin bir yıllık süre içinde paylaştıkları tweet'ler üzerinden nicel içerik analizi tekniğiyle toplanan veriler, betimsel istatistik testleri kullanılarak analiz edilmiştir. Araştırma sonucunda Twitter'ın paydaşlarla diyaloğu ve etkileşimi teşvik etme potansiyeline rağmen, bu işlevin mütevazı bir şekilde kullanıldığı görülmüş̧ür. Çalışma retweet mekanizmasının etkileşimli ve etkin iletişim için kullanılmasının göz önünde bulundurulmasını keşfetmiştir.
Anahtar Kelimeler

Sağlık İletişimi

Sosyal Medya

İçerik Analizi

Twitter

Makale Hakkında

Geliş Tarihi: 22.11.2019

Kabul Tarihi: 10.05.2021

Doi: 10.18026/cbayarsos.649858

\section{Health Communication and Social Media: An Evaluation on Twitter Use of Non- Governmental Organizations}

\begin{abstract}
Health communication is based on communication activities aimed at protecting, improving and enhancing the health of the individual and society. Advances in communication technologies have begun a new era in the reaching of health related information with large audiences. New communication technologies, speed, format of the message sent, the possibility of interactive communication and individual control refers to a technology in which the user. The study aims to reveal how non-governmental organizations use Twitter. The data were collected by using the quantitative content analysis technique over tweets shared by Turkish Cancer Association, Turkish Heart Foundation and Turkish Diabetes Association within a year. The data were analyzed using descriptive statistical tests. The research found that this function was used modestly, despite Twitter's potential to encourage dialogue and interaction with stakeholders. The study explored the use of retweet mechanism for interactive and effective communication.
\end{abstract}

Keywords

\author{
Health Communication \\ Social Media \\ Content Analysis \\ Twitter
}

\begin{tabular}{r} 
About Article \\
\hline Received: 22.11 .2019 \\
Accepted: 10.05 .2021 \\
\end{tabular}

Doi: 10.18026/cbayarsos.649858

\footnotetext{
a Bu çalışma, 7-8 Kasım 2019 tarihinde Eskişehir Anadolu Üniversitesi İletişim Bilimleri Fakültesi tarafından düzenlenen 5. Sağlık İletişimi Sempozyumu'nda sözlü bildiri olarak sunulmuştur.

b İletişim Yazarı: esravonakurt@gmail.com, Dr. Öğretim Üyesi, Isparta Uygulamalı Bilimler Üniversitesi, Isparta Meslek Yüksekokulu, Pazarlama ve Reklamcllık Bölümü,-- https://orcid.org/0000-0001-8639-9160
} 


\section{Giriş}

Bugünün dünyasında medya, iletişim teknolojilerinin gelişimine paralel olarak ilk başvuru kaynağı haline gelmiştir. İnsanı ve toplumu ilgilendiren hemen hemen her konuda, ayrıca toplumun dönüşümünde ve değişiminde önemi yadsınamayan kitle iletişim araçları, günümüzde sağlık alanında da ilk başvuru kaynağı olma özelliğini korumaktadır. İnsanlar karşılaştıkları herhangi bir sağlık problemine ilişkin ya da çeşitli sağlık sorunları hakkında bilgi sahibi olmak istediklerinde, uzman görüşlerine başvurmayı tercih ettiklerinde çoğunlukla medyaya başvurmaktadırlar. Yapılan araştırmalar, kitle iletişim araçlarının sağlık sorunlarıyla ilgili en son gelişmelerden haberdar olmak için faydalı tıbbi bilgiler ileten başlıca bilgi kanalları olarak kabul edildiği sonucunu ortaya çıarmaktadır (Andsager ve Powers, 1999). Medya sadece sağlık alanıyla ilgili tıbbi bilgileri yaymakla kalmaz aynı zamanda sağlığın geliştirilmesinde ve sağlık eğitiminde de önemli bir rol oynamaktadır.

Günümüzde sağllk iletişimi yeni iletişim teknolojilerinin gelişmesine paralel olarak gelişmekte, değişmekte ve dönüşmektedir. Bireyler artık internet teknolojisi aracılığıyla sağlık ile ilişkili her türlü bilgiye ulaşabilmekte, ulaşılan bu bilgileri başka kullanıcılarla paylaşabilmekte, kendisi içerik oluşturabilmekte dolayısıyla sağlık mesajları eskisinden çok daha hızlı bir şekilde geniş kitlelerle buluşabilmektedir. Bu nedenledir ki ulaşılan her bilginin doğru ya da yanlış olduğu bilinmeden yayılması, doğru sağlık iletişimi faaliyetlerinin gerçekleştirilmesini daha da önemli hale getirmektedir. Bu nedenle sağlık alanında faaliyet gösteren kar amacı gütmeyen sivil toplum kuruluşlarının sağlık iletişimi çalışmalarının nasıl ve ne şekilde yapıldığı dikkate değer bir alan olarak karşımıza çıkmaktadır.

Çalışmada amaç, kar amacı gütmeyen sivil toplum kuruluşlarının sağlık bilgilerini yaymak, bireyleri ve toplumu sağlık konusunda bilgilendirmek ve onlarla ilişkiler kurmak ve en önemlisi sağlığ geliştiren eylemleri teşvik etmek için sosyal medya araçlarından biri olan Twitter'ı nasıl kullandıklarını incelemektir. Bu çerçevede çalışmaya kronik olarak tanımlanan hastalıklar konusunda faaliyet gösteren üç sivil toplum kuruluşu dahil edilmiştir. Türk Kanser Derneği, Türk Kalp Vakfı ve Türk Diyabet Cemiyeti'nin bir iletişim ortamı olarak sosyal medyayı nasıl ve ne amaçlarla kullandıkları çalışmanın inceleme konusunu oluşturmaktadır. Araştırmaya dahil edilen üç sivil toplum kuruşunun Twitter'ın etkileşimli özelliklerini kullanmasını incelemek, mesaj işlevlerini ve tweetlerinin konularını anlamak için 15 Ağustos 2018 ve 15 Ağustos 2019 tarihleri arasında paylaştıkları tweetler üzerinden bir içerik analizi yapılmıştır. Araştırmada veriler, içerik analizi tekniği kullanılarak incelenmektedir.

$\mathrm{Bu}$ çerçevede çalışmada öncelikle sağlık iletişimi kavramı ele alınacak, ardından sağlık iletişimi ve sosyal medya ilişkisi değerlendirilecektir. Daha sonra araştırma yöntemi ve kodlama prosedürleri açıklanacak ve inceleme sonucunda elde edilen bulgular değerlendirilecektir. Çalışma, incelenen sivil toplum kuruluşlarının sosyal medya araçlarından biri olan Twitter'1 sağlığı geliştirmek, hastalıkları önlemek ve sağlık eğitimi çerçevesinde nasıl kullandıkları ve temel etkileri tartışmasıyla sona erecektir.

\section{Kavramsal Çerçeve}

\section{Sağlık İletişimini Anlamak}

Disiplinler arası bir alan olarak karşımıza çıkan sağlık iletişimi dünyada ve ülkemizde gelişen ve gittikçe daha belirgin hale gelen bir çalışma alanıdır. Sağlık iletişimi kavramı iletişim, psikoloji, sosyoloji ve tıp gibi birbirinden çok farklı alanları ilgilendiren ve genel olarak sağlık 
bilimleri ile sosyal bilimlerin kesişmesi sonucu 1970’li yıllarda Amerika Birleşik Devletleri'nde ortaya çıkan bir çalışma alanıdır (Hülür, 2015). Disiplinlerarası yapısından dolayı farklı yaklaşımların bulunduğu sağlık iletişimi tanımları incelendiğinde bireylerin, toplumların, sağlık uzmanlarının ve politika yapıcılarının kararları üzerinde etkili bir rol oynadığı ve aynı zamanda sağlığın geliştirilmesinde ve iyileştirilmesinde etkin bir araç olarak işlev gördüğüne dikkat çekilmektedir (Okay, 2009). Yani sağlık iletişimi, sağlık profesyonelleri, sağlık kurumları, sivil toplum örgütleri ve politika yapıcılar tarafından sağlık ile ilgili bilgileri benimsemek, sürdürmek ve nihayetinde sağlık sonuçlarını iyileştirmek amacıyla bireyleri, toplulukları etkilemek ve desteklemek için farklı kitlelere erişmeyi amaçlayan çok yönlü ve çok disiplinli bir yaklaşımdır (Schiavo, 2007).

Piatrow ve arkadaşları (2003), sağlık iletişimine ilişkin dört farklı dönem tanımlamaktadır. Bunlar; tıbbi bakım modeli olarak adlandırılan klinik dönem, proaktif bir yaklaşımı içeren, sosyal yardım çalışanlarının iletişim temelli bilgi ve eğitimini içeren saha dönemi, tüketicilerin istedikleri ürünleri alacağ ticari konseptlerden geliştirilen sosyal pazarlama dönemi ve bugünü içeren sosyal normları ve politika ortamlarını etkileme ihtiyacını vurgulayan davranış bilimi modelleri üzerine kurulu stratejik davranış iletişimi dönemidir. Uzun vadeli bir süreç olarak değerlendirilen iletişim, bireyleri ve onların sağlık sorunlarına ilişkin davranışlarını değiştirmeyi hedefleyen bir çabadır. Sağlık iletişiminde sağlık sorunları ve bunları çözüme ulaştırma yolları üzerinde hedef kitleleri eğitmek, uzun vadeli ve izleyici merkezli süreçtir (Schiavo, 2007). Dolayısıyla sağlık iletişiminin temeli, sağlık hizmeti sunumu ve sağlığın desteklenmesi ile geliştirilmesinde insan ve aracılı iletişimin güçlü rollerine dayanmaktadır (Kreps, Bonguro ve Querly, 1998).

Sağlık iletişimine ilişkin yapılan tanımlamalarda, sadece hasta/doktor ilişkisinin değil, sağlıkla ilgilenen, sağlığıyla ilgilenen herkesin bu iletişim biçiminin içinde yer aldığ 1 görülmektedir. Amerika Birleşik Devletleri'nin (ABD) sağlık kuruluşlarından biri olan "Hastalıkları Kontrol ve Önleme Merkezi" (Centers for Disease Control and Prevention), sağlık iletişimini "sağlı̆̆ geliştirmek, kişilerin ve toplumun sağlıkla ilgili kararlarını iyileştirmek, eylemler hakkında bilgilendirmek ve etkilemek amacıyla iletişim bilimine ilişkin stratejilerin ve kuralların uygulanmasi" (https://www.cdc.gov/healthcommunication/healthbasics), olarak tanımlamaktadır. Sağlık iletişimini insan iletişimin bir alt sistemi olarak değerlendiren Tabak (2003), sağlık hizmetlerinin tanınmasını, doğru sağlık bilgilerinin doğru bir şekilde yayılmasını, bireylerin sağlıkla ilgili tutumlarının değişmesini ve sağlıklı yaşam biçimlerinin temeli olan sağlık davranışının geliştirilmesini sağlık iletişimi kapsamına dahil etmektedir. Sezgin (2010) sağlık iletişimine ilişkin geniş bir tanımlama yapmaktadır. Bireylerin, kurumların, toplumların sağlık ve onunla ilişkili konularda bilinçlendirilmesi ve farkındalık yaratılmasını içeren bu tanımlamada sağlık iletişimi, sağlık alanına ilişkin bilgi ihtiyacının giderilerek, sağlık bilincinin oluşturulmasını kapsamaktadır. Buna paralel olarak sağlık okuryazarlığının oluşturulması ve yükseltilmesini kapsayan bu tanımlamada sağlık iletişiminin çerçevesi, , hasta ya da birey olarak sağlık hakkının tanınması sağlıklı çevrede yaşama hakkının korunması için iletişim strateji ve yöntemlerinin kullanılması olarak çizilmektedir. Çınarlı (2008) ise kavramı iletişim süreci perspektifinden ele alarak sağlıkla ilgili mesajların yayılması, hedef kitleler tarafından anlaşılması ve yorumlanması olarak kavramsallaştırmaktadır. Bu tanımlamadan, mesajı gönderen bir kişi, bir grup, bir kurum, bir kitle iletişim aracı olabileceği gibi mesajı alan ya da yorumlayan tarafın da bir kişi, bir grup, bir kurum ya da bir kitle olabileceği anlaşılmaktadır. 
Aslında, sağlık iletişimi, insanların daha iyi bir yaşam sürmeleri, kendilerinin ve başkalarının tıbbi koşullarını yönetmelerine yardımcı olmayı hedefleyen bilgilendirme ve ikna etme sürecidir (Duffy ve Thorson, 2009). Bu açıdan değerlendirildiğinde sağlık iletişimin temel hedefi insanları sağlık konusunda bilinçlendirmek, sağlıklı yaşam hakkında bilgilendirmek ve sağlıkla ilgili yeniliklerden haberdar ederek sağlığg geliştirmek olduğu söylenebilir (Işık, 2019). $\mathrm{Bu}$ açıdan değerlendirildiğinde sağlık iletişimi, , hastalıkların önlenmesi, hastalık başladıktan sonra doğru tedavi yöntemi hakkında hastaların bilgilendirilmesi ve hastalıkla mücadele etme yolları ile kitleleri sağlık konusunda etkilemeyi ve bilinçlendirmeyi kapsayan gerek yüz yüze iletişim gerekse kitle iletişim araçları yoluyla iletilmesi süreçlerini kapsamaktadır.

Schiavo (2007), sağlık iletişimini içerdiği kavramlara göre belirlenen anahtar kelimeler aracılığıyla değerlendirmektedir. Buna göre ilk nitelik, sağlık konularına ilişskin toplulukları bilgilendirmek, sağlıkla ilgili kararlar üzerinde etkili olmak, bireylerin ve toplumun hastalıklara yakalanmadan önleme davranışlarını benimsemelerini sağlayıcı iletişim teknik ve teknolojilerini kullanmaktır. Bireylerin motivasyonu olarak tanımlanan ikinci nitelik, önemli sağlık sorunlarına ilişkin bireyleri, kuruluşları ve kitleleri etkilemek, bilgilendirmek ve motive etme sanatı olarak değerlendirilmektedir. Davranışları değiştirme olarak tanımlanan üçüncü niteliğe göre sağlık iletişimi önceden tanımlanan bir zaman diliminde, belirlenmiş problemlere yönelik, hedeflenen kitlenin davranışlarını değiştirmek için başvurulan yaklaşım olarak belirtilmektedir. Dördüncü nitelik sağlıkla ilgili konularda bilgilendirmeyi arttırmak, hedef kitleyi bilgilendirerek onların belirli sağlık problemlerini ve yapılacak müdahale yöntemini anlamalarını sağlamaktır. İnsanları güçlendirmek olarak belirlenen beşinci nitelik, özel sağlık sorunları hakkında iletişim sağlayarak insanları güçlendirmektir. Son olarak çift yönlü iletişim ve etkileşim olarak belirlenen altıncı nitelik, iki yönlü etkileşime dayanan bir ortaklık ve katılım sürecine işaret etmektedir.

Sağlık iletişimi, çok çeşitli sosyal bağlamlarda birçok farklı düzey ve iletişim kanalı yoluyla gerçekleşen bir iletişim süreci ve araştırma alanıdır (Kreps, Bonaguro ve Query, 1998). Kreps ve diğerleri (1998) kişisel, kişilerarası, grup, örgütsel ve toplumsal olarak sınıflandırılan bu araştırma alanlarını aşağıdaki gibi açıklamaktadır.

Tablo 1. Sağlık İletişimi Araştırma Alanları

\begin{tabular}{|c|c|c|}
\hline na Alanları & & \\
\hline Kişisel & $\begin{array}{l}\text { Kişinin kendi } \\
\text { zihninde oluşan } \\
\text { sağlık iletişimi } \\
\text { araştırmaları }\end{array}$ & $\begin{array}{l}\text { Sağlık hizmetini etkileyen içsel ve psikolojik süreçleri } \\
\text { incelemekte ve insanların kendi inanç, değer ve } \\
\text { tutumları üzerinden sağlıkla ilgili mesajlar hakkındaki } \\
\text { düşünceleri üzerine odaklanmaktadır. }\end{array}$ \\
\hline Kişiler arası & $\begin{array}{l}\text { Kişilerarası sağlık } \\
\text { iletişimi araştırmaları }\end{array}$ & $\begin{array}{l}\text { Sağlık çıktıları arasındaki ilişkinin etkilerine } \\
\text { odaklanarak, doktor / hasta ilişkisine ve sağlık hizmeti } \\
\text { görüşmelerinde ilgili bilgilerin değiş tokuşunu ele alan } \\
\text { süreçleri incelemektedir. }\end{array}$ \\
\hline Grup & $\begin{array}{l}\text { Grup sağlık iletişimi } \\
\text { araştırmaları }\end{array}$ & $\begin{array}{l}\text { Sağlık ekipleri, destek grupları, etik kurullar ve aileler } \\
\text { gibi kolektif üyelerin birbirine bağımlı } \\
\text { koordinasyonunda üstlenilen rolleri ile ilgili süreçler } \\
\text { üzerinde odaklanmaktadır. }\end{array}$ \\
\hline Örgütsel & $\begin{array}{l}\text { Kurumsal sağlık } \\
\text { iletişimi araştırmaları }\end{array}$ & $\begin{array}{l}\text { Sağlık kurumlarına odaklanan bu çalışma alanında, } \\
\text { karşılıklı bağımlı grupları koordine etmek, farklı }\end{array}$ \\
\hline
\end{tabular}


uzmanları harekete geçirmek ve sağlıkla ilgili etkili multidisipliner sağlık hizmeti sunumunu sağlamaya odaklanan süreçleri konu edinmektedir.

Sağlık eğitimi, sağlığın geliştirilmesi ve sağlık

$\begin{array}{ll}\text { Toplum } & \text { Toplumsal sağlık } \\ \text { iletişimi araştırmaları }\end{array}$ hizmetleri uygulamalarını tanıtmak için çeşitli medya aracılığıyla iletilen ilgili sağlık bilgilerinin geniş bir kitleye iletilmesi, yayılması ve uygulanması ile ilgili süreçleri incelemektedir.

Sağlık iletişimi araştırma alanlarından biri olan toplumsal sağlık iletişimi araştırmaları, medya aracılığıyla iletilen ve sağlık eğitimi, sağlığın geliştirilmesini hedefleyen uygulamaları kapsamaktadır. Bu çerçevede sağlık iletişiminde iletişim sürecine ve medyanın rolüne odaklanan bu alanda, medyanın sağlık bilgisini yaratma, toplama ve paylaşma konusundaki önemli rolüne dikkat çekilmekte ve sağlık iletişimi sürecinde medyanın stratejik sağlık davranışları, tedavileri ve kararlarında rehberlik etme potansiyelinden dolayı, sağlık bilgileri, sağlık bakımı ve sağlığın geliştirilmesinde en önemli kaynak olarak değerlendirilmektedir (Kreps, Bonaguro ve Query, 1998; Parrott, 2004). Özellikle sağlık sorunlarına ilişkin yeniliklerin kamuoyuna duyurulması, istenen sağlık davranışlarının geniş kitleler tarafından benimsenmesinin sağlanması ve çeşitli sağlık kampanyalarının yürütülmesi kitle iletişimiyle mümkündür (Yüksel, Kaya, Koçak ve Aydın, 2014). Yaklaşık yirmi yıl öncesine kadar geleneksel kitle iletişim araçlarıyla (radyo, televizyon, gazete vb.) hastalar ve sağlık hizmeti sağlayıcıları arasındaki kişiler arası etkileşimi kapsayan ve gerçekleştirilen sağlık iletişimi kavramı bir dönüşüm içine girmiştir. Şüphesiz ki bu dönüşümün en önemli ayağını yeni iletişim teknolojileri oluşturmaktadır (Hülür, 2016). Hem geleneksel medya hem de yeni medyanın etkin araçlar olarak kullanımı, yeniliklerin yayılması ve duyurulmasında, bunun yanı sıra bireylere ve topluma yönelik sağlık eğitimi, sağlı̆̆ın geliştirilmesi ve toplumun sağlık konusunda bilinç düzeyinin arttırılmasında çok önemli bir etkiye sahiptir.

\section{Sağlık İletişimi ve Sosyal Medya}

Dünya üzerinde kronik hastalıkların artması, sağlık iletişimi faaliyetlerini daha da önemli hale getirmektedir. Bu kapsamda yapılan ve hedefi sağlığın geliştirilmesi olan bu iletişim faaliyetleri gerek yüz yüze iletişim olanakları gerekse kitle iletişim araçları yoluyla gerçekleşmekte ve sağlık ile ilgili bilgi ve enformasyon geniş kitlelerle buluşturulabilmektedir. Bilindiği gibi medya bilgi ve enformasyonun yayılmasında ve yaygınlaşmasında en etkili araçların başında gelmektedir. Gerek yazılı medya gerek görsel medya gerekse dijital medya olanakları kullanılarak sağlığa ilişkin yenilikler, sağlık eğitimine ilişkin bilgiler, hastalıkların önlenmesi ve tedavi süreçlerine ilişkin yeni yaklaşımlar kitlelere aktarılabilmektedir. Yapılan araştırmalar da medyada yer alan sağlık temalı içeriklerin hedef kitle açısından diğer içeriklere göre daha güvenilir bulunduğunu ortaya koymuştur (Kaya, Yüksel ve Öğüt, 2011).

İletişim teknolojisindeki gelişmeler, sağlık bilgisine erişimde ve yayılımda yeni bir çağı başlatmıştır. Geçmişte, geleneksel medya olarak adlandırılan radyo, televizyon ve yazılı medya (posterler, broşürler ve dergiler dahil) koruyucu sağlı̆̆ın yayılmasında kullanılan baskın tekniklerken, günümüzde bu teknolojilere ek olarak yeni medya olanakları sağlık hizmeti sunan kurum ve kuruluşlara yeni fırsatlar sunmaktadır. Artık bireylere daha fazla sağlık bilgisi ulaştırmak çevrimiçi erişilebilir olmaktan geçmektedir (Bottorf, Struik, Bissell, Graham, Stevens ve Richardson, 2014; Atkinson, Saperstein ve Pleis, 2009). Yeni iletişim 
teknolojilerinin gelişmesi ve yaygın kullanımı sonucu sağlık iletişiminin gerçekleştirildiği en önemli mecralardan biri de günümüzde internet teknolojisidir. Bu çerçevede geleneksel medyaya ek olarak yeni medyanın sağlık profesyonellerine, kurumlara, kuruluşlara sunduğu olanaklar, sağlık iletişimi sürecini de önemli ölçüde etkilemiş ve değiştirmiştir.

İnternet günümüzün en dinamik ve hılı iletişim ortamıdır. Yeni medyanın teknolojisinin sahip olduğu özellikler, sağlık iletişimi sürecini de dönüştürmektedir. Şöyle ki, yeni medya sağlık iletişim sürecinde daha fazla bilginin aynı anda çok sayıda kişiye, çok kısa süreler içinde ulaşabilmesinin yolunu açmıştır. Yer ve zaman sıkıntısı yaşayan geleneksel medyaya göre yer ve zaman sıkıntısı yaşamayan yeni medyada büyük ölçekli bilgi aynı anda ve hızlı bir şekilde geniş kitlelere ulaşabilmektedir. Yeni medya araçları yoluyla oluşturulan mesajın hem yazılı, hem sesli hem de görüntülü gönderilebilme olanağının olması, bilgiye erişen kullanıcının farklı biçimlerde oluşturulan mesajlara ulaşımını sağlamaktadır. Yeni medyanın iki yönlü ve etkileşimli bir iletişimi olanaklı hale getirmesi kullanıcıyı içeriği alan, içerik oluşturan konumu ve gönderilen iletilerin kontrolünün tamamen kullanıcıya ait olması gibi özellikler nedeniyle daha aktif hale getirmiştir. Bu etkileşim kişilerarası iletişimi taklit etmektedir ve internetin iki yönlü iletişimi sağlayan bu özellikleri, sağlık iletişimi süreci için de yeni fırsatlar yaratmaktadir.

Toplum ve bireylerin sağlık konularına ait bilinç düzeyinin arttırılması, hasta bakım hizmetleri konusundaki gelişmeler, hastalıkların önlenmesi için alınacak önlemler ya da genel olarak sağlık hizmetlerinde kalitenin arttırılması sosyal medya mecralarının özelliklerinden dolayı daha hızlı ve daha kolay bir şekilde yapılabilmektedir. Kullanıcıların sağlık hizmetlerine erişiminde ve benzer hastalıklarla mücadele eden diğer kullanıcılarla deneyim paylaşımı, doktorlarla iletişim olanaklarını arttıran sosyal medya araçları, interaktif/etkileşimli doğasıyla sağlık hizmetlerine erişmek isteyenler için de firsatlar yaratmaktadır. Öte yandan yeni iletişim teknolojilerinin gelişimi, sağlıkla ilgili bilinç düzeyinin artmasında da olumlu etki yarattığı söylenebilir. Artık kullanıcıların kendi ya da yakınlarına ilişkin sağlık sorunlarına ilişkin yeni medya dolayımıyla bilgi almanın kolaylaşması, bu bilinç düzeyinin artmasında önemli bir faktör olarak değerlendirilmektedir.

Sağlık iletişiminde yeni medya olanaklarının kullanılması, gerek web temelli olanaklar gerekse sosyal medya ağlarıyla farklı bir evreye geçmiştir. Sosyal medya ağları, kullanıcıların Web 2.0 üzerinden açık ya da yarı açık profil oluşturabilecekleri, kullanıcıların bağlantıda olduğu diğer kullanıcılarla iletişime geçme olanağının olduğu ve kullanıcıların tümü için aynı olanakları sunan bir teknolojiye işaret etmektedir (Kara, 2017). Dolayısıyla sosyal medyanın kullanıcılara sağladığı bu kolaylık nedeniyle hastaneler ve sağlık kuruluşları sağlık iletişimine katkı sağlamak amacıyla bu teknolojiyi etkin bir şekilde kullanmaktadır (Robledo, 2012). Bu bakış açısıyla sosyal medyanın sağlık hizmetine ulaşmada eşitsizliği ortadan kaldırdığı düşünülmektedir. Öte yandan sosyal medya, sağlık alanıyla ilgili bireylerin bilgi düzeyinin artmasına katkı sağladığı ve sağlık bilgileri çerçevesinde tutum ve davranış değişikliği yaratmayı hedefleyen sağlık eğitimi konusunda da kullanıcılara kolaylıklar sağladığ düşünülmektedir (Mendi, 2015).

Ancak konu insan sağlığı olduğundan ve konunun hassasiyetinden dolayı sağlık iletişiminde sosyal medya kullanımı, farklı görüşlerin de ortaya çıkmasına neden olmuştur. İyimser yaklaşımlar yeni medya teknolojisinin sağlık iletişim sürecinin etkili yürütülmesine yönelik büyük fırsatlar doğurduğu ve bu nedenle sağlığın geliştirilmesi ve iyileştirilmesine destek olacağı yönündedir. Sosyal medyanın da aktif olarak kullanıldığı bu süreçte Facebook, Twitter 
gibi platformlar sağlığa ilişkin enformasyonların paylaşımında ve hasta deneyimlerinin aktarılmasında etkin kullanılan araçlar olarak değerlendirilmektedir (Kayabalı, 2011). Moorhead, Hazlett, Harrison, Carroll, Irwin ve Hoving (2013) tarafindan yapılan ve 98 araştırmanın incelendiği çalışmaya göre, İngiltere'de yetişkinlerin \%61'i çevrimiçi arama yapmakta, \%39'u sağlık bilgisine erişebilmek için Facebook gibi kanalları kullanmaktadır. Öte yandan aynı çalışmada sosyal medyanın diyabet, grip, ruh sağlığı gibi konularda sağlık bilgisini paylaşmaya, yorum yapmaya ve tartışmaya imkan sağlayan bir ortam olarak hizmet gördügü ortaya konulmuştur.

Nitekim ABD Centers For Disease Control ve Prevention (ABD Hastalıkları Koruma ve Kontrol Merkezi) (CDC, 2011) tarafından yayınlanan "Sağlık İletişiminde Sosyal Medya Uygulayıcıları için El Kitabı" verilerine göre, son yıllarda sağlık mesajlarının yaygınlaştığ Facebook, YouTube, Twitter ve diğer sosyal medya araçlarının kullanımının arttığına dikkat çekilmektedir. Merkez, sosyal medya araçlarının kullanımının artmasını, bilim temelli sağlığa ve sağlık bilgisine erişimi arttırmanın güvenilir ve etkili bir yolu olarak değerlendirmektedir. CDC, sosyal medya ve yükselen diğer iletişim teknolojilerinin sağlık iletişimi üzerindeki olumlu etkilerini de şu şekilde sıralamaktadır:

a. Sağlık ve hastalıklardan korunmaya ilişkin bilgilerin daha etkili ve hızlı yayılmasını sağlayarak potansiyel etkisinin artmasını sağlar.

b. Bilginin bir ăg üzerinden geniş kitlelerle buluşmasını kolaylaştırır.

c. Belirlenmiş hedef kitlere uygun oluşturulan sağlık mesajlarının kişiselleştirilerek etkisinin artmasını sağlar.

d. Etkileşimli iletişim, bağlantı ve toplumun katılımını kolaylaştırır.

e. İnsanları daha güvenli ve sağlıklı kararlar almasını sağlar.

Öte yandan sağlık alanıyla ilişkili kurum ve kuruluşların sosyal medya kullanımının zaman ve maliyet tasarrufu, pazarlama faaliyetlerinin gelişmesi, rakiplere karşı rekabet üstünlüğü sağlaması gibi avantajlarına dikkat çekilmektedir. Hastalar açısından konu değerlendirildiğinde ise, sağlık bilgilerinin artmasında, hastaların hekim, hastalık ya da hastane hakkında bilgi sahibi olmalarında ve sağlık hizmetine erişiminin arttırılmasında faydalı olduğu belirtilmektedir (İlgün ve Uğurluoğlu, 2016).

Günümüzde sağlık alanıyla ilişkili bilgilerin yayılması ve yaygınlaşmasında geleneksel medyanın tek yönlü olarak aktarılan mesajlarına karşın dijital iletişim araçlarının diyaloga imkan tanıması, çoklu kaynakların çoklu hedef kitlelerle buluşmasını sağlamaktadır (Lilleker, 2013). Pew Research Center' in 2009 yılında yaptığ1 “The Social Life of Health Information" çalışmasına göre (https://www.pewinternet.org/2009/06/11/), internet kullanıcılarının yüzde 57'sinin, sağlık veya sağlıkla ilgili konularla ilgili bilgiye veya yardıma ihtiyacı olduğunda dijital platformlara başvurduğunu göstermektedir. Yine aynı araştırmaya göre, internet kullanıcılarının yaptıkları çevrimiçi sağlık araştırmalarının sağlık kararları ve eylemleri üzerinde olumlu bir etkiye sahip olduğu görülmektedir. Katılımcıların \% 60'ı çevrimiçi bulunan bilgilerin bir hastalığın veya durumun nasıl tedavi edileceğine dair verdikleri kararı etkilediğini, \% 56'sı ise, sağlığını koruma konusundaki genel yaklaşımlarını değiştirdiğini ifade etmektedir. Bireyler kendilerinin ya da yakınlarının yaşadıkları sağlık problemlerine ilişkin hastanelerin, sağlık kurumlarının web sitelerine başvurabilmekte, çevrimiçi bir haber grubunda veya blogda, bir başkasının yorumunu veya tıbbi konularla ilgili deneyimini okumakta, doktorlara ya da diğer hizmet sağlayıcılara başvurabilmekte, sağlık veya tıbbi 
konularla ilgili podcast dinleyebilmektedir. Korda ve Itani (2013) sağlı̆̆ın geliştirilmesi ve sağlık eğitimi amacıyla bloglar, e-oyunlar, RSS Beslemeleri, mesaj panoları, mikrobloglar, kısa mesaj servisleri, sosyal ağ siteleri, video paylaşım siteleri ve wikiler gibi farklı sosyal medya araçlarının kullanıldığını belirtmektedirler.

Madalyonun öteki yüzü, sosyal medyada kullanıcıların da içerik oluşturabilmesinden ve bu içeriklerin hızla yaygınlaşmasından dolayı bazı dezavantajlara sahip olduğu görüşünü içermektedir. Sağlık iletişiminde sosyal medya kullanımına temkinli yaklaşanlar, sosyal medyanın sağlık ile ilgili yanlış bilgilerin yayılmasının yolunu açabileceğini belirtmektedirler. Özellikle sosyal medya araçları yoluyla oluşturulan içeriklerin doğruluğunun kontrol edilmeden hızlı bir şekilde yaygınlaşması, kullanıcıların sağlık konularına ilişkin yanlış bilinçlenmesinin ve insanların sağlığı üzerinde ciddi sonuçlar oluşutrmasının yolunu açtığı düşünülmektedir. Bu nedenle kullanıcıların sosyal ağlarda yayılan her bilginin doğru olmayabileceği temel ilkesinden hareket etmesi gerektiği konusuna dikkat çekilmektedir (Atkinson, Saperstein ve Pleis, 2009). Sosyal medyada sağlıkla ilgili içeriklerin yanlış ve hatalı olabileceği, sansasyonel içerik üretme kaygısıyla konunun özünün kaybolabileceği, yanıltıcı içerikler nedeniyle sağlık alanının ticarileşmesini hızlandıracağı (Atabek, Atabek ve Bilge, 2013) bu sonuçlardan bazıları olarak kaydedilmektedir. Öte yandan konuyu internet kullanımına erişemeyenler açısından değerlendiren Atkinson ve diğerleri (2009), bu kesimin sosyal ağlardaki bilgi akışından yoksun kalmasını da olumsuz bir durum olarak değerlendirmektedir.

Sağlık iletişiminde sosyal medya araçlarının yaygın bir şekilde kullanılması ve özellikle bireylerin internet teknolojilerinden faydalanarak kendi sağlıklarıyla ilgili üzerlerine düşen sorumluluğu yerine getirmesi beklenmektedir. Bu noktada dikkat çekilmesi gereken belki de en önemli nokta gittikçe ticarileşen sağlık hizmetleri konusunda bireyin kendi başına yapabileceklerinin sınırlı kalmasıdır. Bu nedenle özellikle politika oluşturucuların bireyi koruyan sağlık politikalarını geliştirmesi, çeşitli yasa ve düzenlemelerin yapılmasının yanı sıra sağlık iletişimi taraflarından kar amacı gütmeyen sivil toplum kuruluşlarına önemli görevler düşmektedir. Başka bir ifadeyle ticari kaygı beslemeyen kurum ve kuruluşların doğru, etkili, bilgilendirici ve sağlı̆̆ geliştirici iletişim faaliyetleriyle bireyin, doğru sağlık bilgisine erişmesinin yolu açılmış olmaktadır.

\section{Etkileşim ve Diyalog Kurmanın Bir Aracı Olarak Twitter}

Yeni iletişim teknolojilerinin gelişmesi ve internet erişiminin artması, bu ortamın kullanımını da günden güne artırmaktadır. "We Are Social ve Hootsuite"ın 2018 Global Digital Raporu, dünyada dört milyardan fazla insanın internet kullandığını ortaya koymaktadır (https://wearesocial.com/blog/2018/01/global-digital-report-2018). Rapora göre, dünyada 4 milyar 21 milyon kişi internet kullanırken, Türkiye'de bu rakam 54 milyon 330 bin kişidir. Sosyal medya kullanım rakamlarına bakıldığında ise dünyada 4 milyar 797 milyon kişi çeşitli sosyal medya platformlarında (YouTube, Instagram, Facebook, Twitter v.b.) kullanıciyken, Türkiye'de bu platformlarda 152 milyondan fazla kullanıcı bulunmaktadır.

Blog ve anlık mesajlaşma arasındaki bir eylemi ifade eden bir mikroblog servisi olan Twitter, mobil aygıtlar üzerinden üretilen içeriklerin hızlı paylaşımını kapsamaktadır. Kullanıcı, Twitter'da paylaştığı bir içeriği başka birçok cihazda görüntüleyebilmekte ve diğer sosyal medya mecralarında paylaşarak içeriği taşıyabilmektedir. Twitter'ın dört ana kullanım alanı bulunmaktadır. Bunlar, "günlük sohbetler", "konuşmalar", "bilgi paylaşımı" ve "haber 
paylaşımı" (Java, Song, Finin ve Tseng, 2007) olarak sıralanmaktadır. Yayın medyasının ve yüz yüze iletişimin özelliklerini birleştiren (Marwick ve Boyd, 2010) bu platform, etkili bir sosyal medya platformudur.

Tablo 2. Twitter' in Özellikleri

\begin{tabular}{|c|c|}
\hline Özellikler & Tanım \\
\hline Tweet & $\begin{array}{l}\text { Metin içeren mesajlardır ve kullanıcılar bu mesajlar yoluyla duygularını, düşüncelerini, } \\
\text { kurumsal paylaşımları takipçilerine iletebilmektedir (Conover, Gonçalves, Flammini ve } \\
\text { Menczer, 2012). }\end{array}$ \\
\hline Retweet & $\begin{array}{l}\text { Twitter'daki mesajların yayılması için gerekli bilgiyi yaymanın hızlı, etkileşimli bir yolu } \\
\text { olarak değerlendirilmekte ve çoğunlukla ilgi çekici ve beğenilen içerikleri diğer } \\
\text { kullanıcılarla paylaşmak amacıyla kullanılmaktadır (Lee ve Xu, 2018). "Retweet", } \\
\text { paylaşılan içeriğin görünürlüğünü arttıran bir mekanizma olarak işlev görmektedir. }\end{array}$ \\
\hline Mention & $\begin{array}{l}\text { Twitter kullanıcıları yönlendirmek istedikleri mesajları ya da diğer kullanıcıların } \\
\text { gönderdikleri mesajları okuyabilmelerini sağlamak amacıyla "mention” olarak } \\
\text { adlandırılan işaretleme biçimini kullanmaktadırlar. “Mention" gönderilen tweetin içine } \\
\text { “@Kullanıcı Adı" şeklinde tanımlanmaktadır. Tweetlerin içine yerleştirilen "mention”lar, } \\
\text { gerçek etkileşimi temsil ederken, üçüncü şahıs referansını oluşturmaktadır (Conover, } \\
\text { Gonçalves, Flammini ve Menczer, 2012). }\end{array}$ \\
\hline Hashtag & $\begin{array}{l}\text { Hashtag, Twitter'da kullanılan konu etiketlerini tanımlamada kullanılmaktadır. } \\
\text { Gönderilen tweetin içine “\#konu etiketi” şeklinde tanımlanan hashtag'ler tweet } \\
\text { konusunu tanımlamakta, ayrıca bu etiketi Twitter'da arayan kullanıcıların da paylaşılan } \\
\text { tweeti okuyabilmesini sağlamaktadır. }\end{array}$ \\
\hline Fotoğraf & Bir tweet'e bir fotoğraf eklenebilir. \\
\hline Video & $\begin{array}{l}\text { Bir video (veya bir videonun bağlantısı) bir tweet'in içine eklenebilir ve bir kullanıcının } \\
\text { Twitter yayınında oynatılabilir. }\end{array}$ \\
\hline Hyperlink & Diğer kullanıcıları Twitter dışındaki içeriğe yönlendirmek için bir bağlantı eklenebilir. \\
\hline
\end{tabular}

Sosyal paylaşım sitesi Twitter'ın popülaritesinin artması ve sağlık hizmeti veren kuruluşların paydaşlarıyla iletişim kurmaları için benimsemeleri, bu alanın dikkate değer olduğunun göstergesidir. Twitter gibi sosyal ağ siteleri, hedef kitlelerini kendileriyle etkileşimli iletişime dahil etmek için geniş bir yelpazede fırsatlar sunmaktadır (Rybalko ve Seltzer, 2010; Lovejoy ve Saxton, 2012). Sağlık iletişiminde de yaygın olarak kullanılan bir sosyal medya kanalı olan Twitter, hastalığın önlenmesi, sağlığın geliştirilmesi ve sağlık eğitimi konusunda geniş imkanlar sunmaktadır (Thackeray, Neiger ve Keller, 2012). Öte yandan Twitter kullanıcı dostu bir araçtır ve bir sağlık kuruluşu, kullanıcılarını korumak için kuruluşla ilgili haberlere bağlantılar ekleyerek takipçilerin doğru sağlık bilgilerine erişimini sağlayabilmekte ve takipleri teşvik etmek için Twitter'ın özelliklerinden yararlanabilmektedirler (Rybalko ve Seltzer, 2010).

Sağlık iletişimi çerçevesinde sağlık kuruluşları ve kar amacı gütmeyen sivil toplum kuruluşlarının bu alanda önemli aktörler olduğu düşünülmektedir. Daha önce bu alanda yapılan çalışmalara göre, (Kent, Taylor ve White, 2003; Saxton, Guo ve Brown, 2007) kar amacı gütmeyen sivil toplum kuruluşlarının web sitelerini etkileşimli ve paydaş katılımını arttıran stratejik bir iletişim aracı olarak kullanamadığını göstermektedir (Lovejoy ve Saxton, 2012). Bu 
nedenle sosyal medyanın kar amacı gütmeyen sivil toplum kuruluşları için etkileşimli ve katılımın sağlandığı, neredeyse gerçek zamanlı iletişim kurabilecekleri bir fırsat yarattığ düşünülmektedir.

Özellikle sağlık hizmetlerinin ticarileştiği bir dönemde kar amacı gütmeyen kuruluşların, sağlığın geliştirilmesi, hastalıkların önlenmesi ve sağlık eğitimi çerçevesinde takipçileri ve diğer kullanıcılarla iletişim kurmada etkileşimi arttıran bir kanal olan Twitter kilit özellikte bir platform olarak değerlendirilmektedir. Dolayısıyla bu platformun özelliklerinin sivil toplum kuruluşları tarafından nasıl kullanıldığına bakmak bilgilendirici ve aydınlatıcı olacaktır.

\section{Yöntem}

\section{Araştırma Modeli}

$\mathrm{Bu}$ çalışma, kar amacı gütmeyen ve sağlık alanında faaliyet gösteren üç sivil toplum kuruluşunun 15 Ağustos 2018 - 15 Ağustos 2019 tarihleri arasında sosyal medya araçlarından biri olan Twitter'ı sağlık iletişimi çerçevesinde nasıl kullandıklarını ortaya koymayı amaçlamıştır. Bu çerçevede kronik olarak tanımlanan hastalıklar konusunda sağlık bilgilerini yaymak, sağlık eğitimi ve sağlığı geliştirmek adına bireyleri ve toplumu bilgilendirme amacı güden Türk Kanser Derneği, Türk Kalp Vakfı ve Türk Diyabet Cemiyeti ülkemizin sağlık alanında köklü sivil toplum kuruluşları olması nedeniyle araştırmaya dahil edilmiştir.

Çalışmada belirlenen sivil toplum kuruluşlarının bir yıl süreyle Twitter üzerinden sağlık iletişimi bağlamında paylaştıkları tweetler üzerinden bir inceleme yapılmıştır. Tanımlayıcı/betimleyici bir araştırma deseni üzerinden yapılandırılan çalışmada veriler, içerik analizi tekniğiyle incelenmiştir. Çalışmada analiz, üç temel araştırma perspektifine dayandırılmıştır.

a. Kar amacı gütmeyen sivil toplum kuruluşlarının Twitter profillerinin (takipçi sayıları, takip ettikleri, paylaşılan tweetlerin sayısı gibi) incelenmesi,

b. Kar amacı gütmeyen sivil toplum kuruluşlarının Twitter' daki etkileşim türlerinin ("retweet", "hashtag", "mention"ve diğer kullanıcıların "retweet" ve "beğeni (like)" bilgileri gibi) ve Twitter özelliklerini kullanım biçimlerinin incelenmesi,

c. Kar amacı gütmeyen sivil toplum kuruluşlarının tweet'lerinin içeriklerinin ve tweet işlevlerinin incelenmesi.

\section{Evren ve Örneklem}

Zengin bilgi içerdiği düşünülen vakaların / konuların çalışılmasını sağlayan (Patton, 2002) bir teknik olarak değerlendirildiğinden, çalışmanın örneklemi "amaçlı örnekleme" tekniği kullanılarak belirlenmiştir. Amaçlı örnekleme, evrene ilişkin daha önceden elde edilmiş bilgiler çerçevesinde, araştırmacının kendi bilgisine ve özel amaçlara dayanarak bir örneklem oluşturulmasını kapsamaktadır (Eryılmaz, 2011). Bu araştırma, temel veri kaynağı olarak kar amacı gütmeyen sivil toplum kuruluşlarından çalışmanın hedefleri doğrultusunda amaçlı örnekleme tekniği ile Türk Kanser Derneği, Türk Kalp Vakfı ve Türk Diyabet Cemiyeti'nin 15 Ağustos 2018 - 15 Ağustos 2019 tarihleri arasında paylaştıkları tweet'leri kullanmaktadır. Çalışmanın örneklemine birden fazla tweet'den oluşan tweet dizileri tümüyle değil sadece kurumun paylaştığı başlangıç tweet'i dahil edilerek oluşturulmuştur. Twitter'daki verilerin kayıt altına alınabilmesi, geçmişe yönelik incelemeleri mümkün kılarken, paylaşılan 
tweet'lerin kaydedilmesi olanağını da yarattığı için her kurum tarafından gönderilen tweet içerikle birlikte (ses, video, fotoğraf vb.) listelenmiş ve kaydedilmiştir.

\section{Veri Analiz Tekniği}

Araştırmada kullanılan içerik analizi tekniği, "metinlerin ya da diğer anlamlı durumların kullanım bağlamlarından yinelenebilir ve geçerli sonuçlar çıkarmak için yapılan bir araştırma tekniği" (Krippendorff, 2004, s. 18) olarak tanımlanmaktadır. İçerik analizi tekniği, iletişimsel metinlerde ortaya konulan mesajların örtük ya da açık anlamlarını belirlemeye yarayan (Fiske, 1997, s. 176) bilimsel bir araçtır. Buna göre araştırmanın verileri, çalışmaya dahil edilen üç sivil toplum kuruluşunun kurumsal Twitter hesaplarından (Tablo 3) elde edilmiştir.

Tablo 3. Sivil Toplum Kuruluşlarının Twitter Hesapları

\begin{tabular}{ll}
\hline Sivil Toplum Kuruluşları & \multicolumn{1}{c}{ Twitter Hesapları } \\
\hline Türk Kalp Vakfı & @turkkalpvakfi \\
Türk Diyabet Cemiyeti & $@$ DiyabetCemiyeti \\
Türk Kanser Derneği & $@$ TKanserDernegi \\
\hline
\end{tabular}

Çalışmanın araştırma soruları şu şekilde belirlenmiştir:

a. Sağlık kuruluşlarının Twitter profillerinin özellikleri nelerdir?

b. Sağlık kuruluşları Twitter'ın özelliklerini (retweet, mention, hashtag, fotoğraf, video, hyperlink vb.) nasıl kullanmaktadır?

c. Sağlık kuruluşlarının tweet'leri hangi konuları kapsamaktadır?

d. Sağlık kuruluşlarının tweet'lerinin içeriğine dayanarak hangi mesaj işlevini yerine getirmektedir?

Çalışmanın araştırma soruları çerçevesinde kodlama kategori birimleri üç temel perspektife dayandırılarak oluşturulmuştur. Bu kodlama kategorileri, sosyal medyaya yönelik daha önce yapılmış çalışmalardan model alınmış (Lovejoy ve Saxton, 2012; Neiger, Thackeray, Burton, Thackary ve Reese, 2013; Park, Reber ve Gi-Chon, 2016) ve alanında uzman üç akademisyenin görüşleri alınarak hazırlanmıştır. Uzman tavsiyeleri doğrultusunda kodlama kategorileri, kurumların Twitter üzerinden oluşturdukları içerikleri yansıtacak şekilde düzenlenmiştir. Örneğin model alınan çalışmada "topluluk" olarak ifade edilen işlev, ilgili sosyal medya terminolojisine uygun olarak "katılım" şeklinde değiştirilmiştir. Yine model alınan çalışmalarda bulunmayan ancak araştırmaya dahil edilen sivil toplum kuruluşlarının tweet'lerinin incelenmesinden sonra ortaya çıkan "diğer" kategorisi yeni bir kategori olarak eklenmiştir. Bu kategoriye kutlama, anma, bayram mesajlarıla kamunun gündemine ve hassasiyetlerine ilişkin tweet'ler dahil edilmiştir.

Çalışmada ilk olarak sağlık kuruluşlarının Twitter profillerini analiz etmeyi hedefleyen kategoriler oluşturulmuştur. Kurumların Twitter profillerinin etkisini ölçmek adına takipçi sayıları, takip ettikleri diğer kullanıcıların sayısı, bu güne kadar paylaştıkları tweet'lerin sayısı gibi bilgiler, kurumsal hesaplar üzerinden elde edilmiştir. Çalışmada ikinci olarak sağlık kuruluşları tarafından Twitter'ın özelliklerinin (retweet, mention, hashtag, fotoğraf, video, hyperlink vb.) nasıl kullanıldığını belirlemek amacıyla tweet türü (ör. @ - reply, retweet), 
paylaşılan tweet'de hyperlink, fotoğraf gibi görsel malzemeye yer verilip verilmediği ve Twitter'ın özellikleri içinde yer alan "retweet", "hashtag" ve "mention" bilgileri analiz edilmiştir. Ayrıca etkileşiminin bir boyutu olarak değerlendirilen "beğeni" bilgileri de değerlendirilerek tanımlanmıştır. Çalışmada son olarak sağlık kuruluşlarının tweet'lerinin hangi konuda paylaşıldığı ve paylaşılan tweet'in içerik olarak hangi işlevi yerine getirdiği incelenmiştir. Paylaşılan tweet'lerin konuları temelde iki kategoriye ayrılmıştır. Bu kategoriler "kuruma ait paylaşım" ve "kişisel sağlığa yönelik paylaşım"lardır. Bu kategoriler de kendi aralarında paylaşılan mesajın işlevini belirlemek adına bilgi, topluluk oluşturma ve eylem olmak üzere üç birimde analiz edilmiştir. Her iki kategoriye ait paylaşımlar, belirlenen alt birimler çerçevesinde ayrı ayrı kodlanmıştır. Bilgi paylaşımı, organizasyondan topluma bilgi alışverişi olarak tanımlanmıştır. Eylem, takipçilerin organizasyon için bir şeyler yapmasını amaçlayan mesajlar veya bireylerin kişisel sağlıkları için harekete geçmesini amaçlayan mesajlar olarak belirlenmiştir. Katılım ise Twitter'ın takipçilerle çevrimiçi bir topluluk yaratılmasını kolaylaştıracak şekilde paydaşlarla etkileşimde bulunmak, paylaşmak ve sohbet etmek için kullanılması olarak değerlendirilmiştir.

Tablo 4. Tweet Konularına ve Mesaj Fonksiyonlarına Yönelik Kodlama Kategorileri

\begin{tabular}{|c|c|}
\hline Mesaj Fonksiyonları & Konu \\
\hline $\begin{array}{l}\text { Kurumun faaliyetlerine } \\
\text { ilişkin bilgi verme (bilgi) }\end{array}$ & $\begin{array}{l}\text { İnsanları kuruluşun hizmetleri, eğitim programları veya } \\
\text { etkinlikleri hakkında bilgilendirmek. }\end{array}$ \\
\hline Takipçilerle iletişim (katılım) & $\begin{array}{l}\text { Takipçilerini tanıma ve teşekkür etme ya da diğer kullanıcıların } \\
\text { sorularına veya yorumlarına cevap vermek. }\end{array}$ \\
\hline $\begin{array}{l}\text { Kurumun faaliyetlerine } \\
\text { katılmaya teşvik etmek } \\
\text { (eylem) }\end{array}$ & $\begin{array}{l}\text { Diğer kullanıcıları geri bildirimde bulunmaya veya kurumun } \\
\text { faaliyetlerine aktif olarak katılmaya teşvik etmek. }\end{array}$ \\
\hline $\begin{array}{l}\text { Kişisel Sağlık konularına } \\
\text { ilişkin bilgi verme (bilgi) }\end{array}$ & $\begin{array}{l}\text { Genel halk sağlığı bilgilerini sağlamak (örneğin, sağlık önerileri ve } \\
\text { önleyici tedbirler). Öte yandan insanları sağlık riskleri hakkında } \\
\text { bilgilendirmek ve sağlık politikaları ve sağlık hizmetleri sistemleri } \\
\text { gibi sosyal veya politik sorunları ele almak. }\end{array}$ \\
\hline $\begin{array}{l}\text { Kişisel Sağlık konularına } \\
\text { ilişkin eyleme geçmeye teşvik } \\
\text { etmek (eylem) }\end{array}$ & $\begin{array}{l}\text { İnsanları koruyucu sağlık taraması almaya, yaşam tarzlarını } \\
\text { değiştirmeye veya sağlık davranışlarını sürdürmeye teşvik etmek } \\
\text { ve sağlık sorunlarına ilişkin daha fazla bilgi edinmek için harekete } \\
\text { geçmelerini istemek. }\end{array}$ \\
\hline Diğer & $\begin{array}{l}\text { Kutlama, anma, bayram mesajlarıyla kamunun gündemine ve } \\
\text { hassasiyetlerine duyarlı olmak. }\end{array}$ \\
\hline
\end{tabular}

\section{Güvenilirlik}

Araştırmada kullanılan içerik analizinin güvenilirliği tekrarlanabilirlik (reproducibility) (Krippendorf, 2004) testiyle ortaya konulmuştur. Bu teste göre farklı kodlayıcılar, farklı mekan ve koşullarda aynı veri setini kodlamıştır. Birbirinden bağımsız olarak gerçekleşen bu kodlama işleminde, kodlayıcılar arasında tutarlılık ve tutarsızlık ölçülmektedir. İki araştırmacı bu testi uygulamış ve kodlama yönergesinde uzlaşılan ve ayrılan noktalar Neuendorf'un (2002) formülüne (Güvenilirlik= A/N) uygulanmıştır. Bu formüle göre A görüş birliğine (agreement) varılan kodlama birimlerini temsil ederken, $\mathrm{N}$ kodlanan toplam yönerge sayısını 
ifade etmektedir. Farklı zaman ve koşullarda yapılan kodlamalarda, her iki araştırmacının kodlamalardaki görüş birliğine varılan ve varılmayan sonuçlar formüle uygulanmıştır. Bu formüle göre, tekrarlanabilirlik testinde kodlayıcıların güvenilirliği .83 olarak bulunmuştur. Krippendorff (2004), .80 ve üzerindeki bir değerin güvenilir kabul edildiğine dikkat çekerken, çalışmada kullanılan veri toplama aracı bu ölçüler içinde yer aldığından güvenilir bir araç olarak değerlendirilmektedir.

\section{Bulgular}

\section{Sivil Toplum Kuruluşlarının Twitter Profillerinin Özelliklerine ilişkin Bulgular}

Araştırmaya dahil edilen sivil toplum kuruluşlarının Twitter profillerine ilişkin bulgular aşağı da Tablo 5'de gösterilmektedir.

Tablo 5. Sivil Toplum Kuruluşlarının Twitter Profilleri

\begin{tabular}{|c|c|c|c|c|}
\hline Kuruluşlar & $\begin{array}{c}\text { Twitter } \\
\text { Katılım Tarihi }\end{array}$ & Takip Edilenler & Takipçiler & $\begin{array}{c}\text { Paylaşılan Tweet } \\
\text { Sayısı }\end{array}$ \\
\hline Türk Kalp Vakfı & Ekim 2011 & 12 & 1586 & 746 \\
\hline $\begin{array}{l}\text { Türk Diyabet } \\
\text { Cemiyeti }\end{array}$ & A ğustos 2013 & 311 & 2080 & 1382 \\
\hline $\begin{array}{l}\text { Türk Kanser } \\
\text { Derneği }\end{array}$ & Şubat 2014 & 22 & 3388 & 607 \\
\hline
\end{tabular}

Araştırmaya dahil edilen sivil toplum kuruluşlarının Twitter profilleri incelediğinde üç kurumun da uzun yıllardır kurumsal olarak Twitter kullandıkları görülmektedir. Türk Kalp Vakfı sekiz, Türk Diyabet Cemiyeti altı, Türk Kanser Derneği de beş yıldır Twitter kullanıcısı olarak görülmektedir. Takip edilen ve takipçi sayıları değerlendirildiğinde bütün kurumların takipçi sayılarının ve takip ettikleri diğer kullanıcıların sayılarının az olduğu ve bu sonuçlar Twitter kullanıcısı olarak aktif olmadıklarını göstermektedir. En yüksek takipçi sayısına Türk Kanser Derneği sahipken, onu Türk Diyabet Cemiyeti ve Türk Kalp Vakfı izlemektedir. Takip edilenlerde ise Türk Diyabet Cemiyeti 311 hesabı, Türk Kanser Derneği 22 hesabı, Türk Kalp Vakfı ise 12 hesabı takip etmektedir. Bu durum temeli etkileşime ve diyaloğa dayanan Twitter'ın sivil toplum kuruluşları tarafından tek yönlü olarak kullanıldığını ancak bu kullanımın da Twitter platformunda diğer kullanıcılarda takip isteği uyandırmadığını, başka bir ifadeyle çok etkili olmadığını göstermektedir.

Tablo 6. Sivil Toplum Kuruluşlarının Yıllara Göre Tweet Sayıları

\begin{tabular}{lccc}
\hline Kuruluşlar & $\mathbf{2 0 1 8}$ & $\mathbf{2 0 1 9}$ & Toplam \\
\hline Türk Kalp Vakfı & $55(\% 31.4)$ & $120(\% 68.6)$ & $175(\% 74.8)$ \\
Türk Diyabet Cemiyeti & $49(\% 90.7)$ & $5(\% 9.3)$ & $54(\% 23.1)$ \\
Türk Kanser Derneği & $3(\% 60)$ & $2(\% 40)$ & $5(\% 2.1)$ \\
Toplam & $107(\% 45.7)$ & $127(\% 54.3)$ & $234(\% 100)$ \\
\hline
\end{tabular}

Çalışmaya dahil edilen üç sivil toplum kuruluşunun 15 Ağustos 2018 ve 15 Ağustos 2019 tarihleri arasında paylaştıkları tweet'lere bakıldığında en fazla tweet'i Türk Kalp Vakfı'nın 
paylaştığ1 görülmektedir. Kurum, 2018 yılında 55 (31.4\%), 2019 yılında 120 (68.6\%) tweet paylaşmıştır. İkinci sırada Türk Diyabet Cemiyeti yer almaktadır. Kurum 2018 yılında 49 (90.7\%) tweet paylaşırken 2019 yılında 5 (9.3\%) tweet paylaşmıştır. Türk Kanser Derneği ise 2018 ve 2019 yıllarında toplam 5 tweet paylaşarak, en az tweet paylaşan kurum olmuştur.

\section{Sivil Toplum Kuruluşlarının Twitter'ın Özelliklerini Kullanımına Yönelik Bulgular}

Bu bölümde kuruluşların öncelikle tweet türü (orijinal tweet, retweet, reply) tanımlanmıştır. Daha sonra paylaşılan tweet'de hyperlink, fotoğraf, video paylaşımı yapılıp yapılmadığı değerlendirilmiştir. Kuruluşların diğer kullanıcılarla etkileşiminde önemli Twitter özelliği ve araçları olan mention ve hashtag kullanımı tespit edilmiştir. Öte yandan kuruluşların paylaştıkları tweet'lerin "retweet" ve "like (beğeni)" oranları, diğer kullanıcılarla kuruluşlar arasındaki etkileşimli iletişimin bir unsuru olarak değerlendirilerek bu bilgiler de araştırmaya dahil edilmiştir.

Tablo 7. Sivil Toplum Kuruluşlarının Tweet Türü

\begin{tabular}{lcccc}
\hline Kuruluşlar & Orijinal Tweet & Retweet & Reply & Toplam \\
\hline Türk Kalp Vakfı & $173(\% 98.9)$ & $2(\% 1.1)$ & $0(\% 0)$ & $175(\% 74.8)$ \\
Türk Diyabet Cemiyeti & $54(\% 100)$ & $0(\% 0)$ & $0(\% 0)$ & $54(\% 23.1)$ \\
Türk Kanser Derneği & $5(\% 100)$ & $0(\% 0)$ & $0(\% 0)$ & $5(\% 2.1)$ \\
Toplam & $232(\% 99.1)$ & $2(\% 0.9)$ & $0(\% 0)$ & $234(\% 100)$ \\
\hline
\end{tabular}

Çalışmaya dahil edilen kuruluşların paylaştıkları içeriklerin kendi hazırladıkları orijinal tweet'lerden oluştuğu görülmektedir. Türk Kalp Vakfı \%98.9 oranında orijinal tweet paylaşırken, diğer kuruluşlarda bu oran \%100 şeklindedir.

Tablo 8. Sivil Toplum Kuruluşlarının Twitter'ın Özelliklerini Kullanımı

\begin{tabular}{lcccc}
\hline Özellikler & Kalp & Diyabet & Kanser & Toplam \\
\hline Hyperlinks & $101(\% 57.7)$ & $4(\% 7.4)$ & $2(\% 40)$ & $107(\% 45.7)$ \\
Fotoğraf & $169(\% 96.6)$ & $37(\% 68.5)$ & $4(\% 80)$ & $210(\% 89.7)$ \\
Video & $2(\% 1.1)$ & $0(\% 0)$ & $0(\% 0)$ & $2(\% 0.9)$ \\
Mention & $32(\% 18.3)$ & $0(\% 0)$ & $2(\% 40)$ & $34(\% 14.5)$ \\
Hashtag & $170(\% 97.1)$ & $34(\% 63)$ & $2(\% 40)$ & $206(\% 88)$ \\
\hline
\end{tabular}

Sivil toplum kuruluşlarının diğer kullanıcıları Twitter dışındaki içeriğe yönlendirmek için ekledikleri hyperlinks bağlantıları değerlendirildiğinde Türk Kalp Vakfı'nın \%57.7 oranında tweet'lerini bir bağlantıyla paylaştığ 1 görülmektedir. Çalışmaya dahil edilen sivil toplum kuruluşlarının paylaştıkları tweetlerin büyük çoğunluğunun fotoğraf eşliğinde paylaşıldığ görülmektedir. Türk Kalp Vakfı \%96.6, Türk Diyabet Cemiyeti \%68.5, Türk Kanser Derneği $\% 80$ oranında paylaşımlarını fotoğraflı olarak paylaşmıştır. Kuruluşların oluşturdukları içeriklere video eklemedikleri görülmektedir. Twitter' da diğer kullanıcılarla gerçek etkileşimi 
temsil eden ve üçüncü şahıs referansını oluşturan "mention (@kullanıcı adı)" kullanımı tweet sayılarına göre değerlendirildiğinde en fazla kullanım (32 tweet) Türk Kalp Vakfı'nda görülmektedir. Türk Diyabet Cemiyeti hiç mention kullanmazken, Türk Kanser Derneği paylaştığı beş tweet'den ikisini mention bilgisi ile paylaşmıştır. Twitter'da kullanılan konu etiketlerini tanımlamada kullanılan "hashtag", bu etiketi Twitter'da arayan kullanıcıların da paylaşılan tweeti okuyabilmesini sağlayan bir araçtır. "Hashtag" kullanımının araştırmaya dahil edilen 3 sivil toplum kuruluşu tarafından etkin kullanıldığ görülmektedir. Türk Kalp Vakfı \%97.1 oranında, Türk Diyabet Cemiyeti \%63 oranında, Türk Kanser Derneği de \%40 oranında içeriklerini hashtag kullanarak paylaşmıştır.

Sivil toplum kuruluşlarının diğer kullanıcılarla etkileşiminin bir boyutu olan "retweet" ve "like (beğeni)" oranları değerlendirildiğinde, takipçi sayılarının azlığı ve etkileşim yollarını etkin kullanamamalarından dolayı bu oranların az olduğu görülmektedir. Türk Kalp Vakfı \%65.1 oranında, Türk Diyabet Cemiyeti \%40.7 oranında, Türk Kanser Derneği de \%20 oranında hiç retweet almamıştır.

Tablo 9. Sivil Toplum Kuruluşlarının Paylaşımlarının Retweet Oranı

\begin{tabular}{lcccc}
\hline Kuruluşlar & Retweet (0-50) & Retweet (51-100) & Yok & Toplam \\
\hline Türk Kalp Vakfı & $61(\% 34.9)$ & $0(\% 0)$ & $114(\% 65.1)$ & $175(\% 74.8)$ \\
Türk Diyabet Cemiyeti & $31(\% 57.4)$ & $1(\% 1.9)$ & $22(\% 40.7)$ & $54(\% 23.1)$ \\
Türk Kanser Derneği & $4(\% 80)$ & $0(\% 0)$ & $1(\% 20)$ & $5(\% 2.1)$ \\
Toplam & $96(\% 41)$ & $1(\% 0.4)$ & $137(\% 58.5)$ & $234(\% 100)$ \\
\hline
\end{tabular}

Sivil toplum kuruluşlarının paylaştıkları içeriklerinin "like (beğeni)" oranları da benzer şekildedir. Çalışmaya dahil edilen kuruluşların paylaştıkları tweet'lerin büyük çoğunluğu 050 arası beğeni almıştır. Bu oran Türk Kalp Vakfı'nda \%87.4, Türk Diyabet Cemiyeti'nde $\% 83.3$, Türk Kanser Derneği'nde ise \%60'dır.

Tablo 10. Sivil Toplum Kuruluşlarının Like Oranı

\begin{tabular}{lcccc}
\hline Kuruluşlar & Like (0-50) & Like (51-100) & Yok & Toplam \\
\hline Türk Kalp Vakfı & $153(\% 87.4)$ & $1(\% 0.6)$ & $21(\% 12)$ & $175(\% 74.8)$ \\
Türk Diyabet Cemiyeti & $45(\% 83.3)$ & $0(\% 0)$ & $9(\% 16.7)$ & $54(\% 23.1)$ \\
Türk Kanser Derneği & $3(\% 60)$ & $0(\% 0)$ & $2(\% 40)$ & $5(\% 2.1)$ \\
Toplam & $201(\% 85.9)$ & $1(\% 0.4)$ & $32(\% 13.7)$ & $234(\% 100)$ \\
\hline
\end{tabular}

Sivil Toplum Kuruluşlarının Paylaştıkları Tweetlerin Konu ve İşlevlerine İlişkin Bulgular

Sivil toplum kuruluşlarının paylaştıkları tweet'lerin içerikleri temelde iki kategoriye ayrılarak incelenmiştir. Organizasyonla ilişkili içerikler ve insan odaklı içerikler olarak ayrılan bu iki kategori kendi içinde de sınıflandırılmıştır. Bunlar, kurumun faaliyetleri hakkında bilgi vermek, kurumun faaliyetlerini teşvik etmek, kurumun hedef kitleleri ile çevrimiçi topluluk 
oluşturmak, kişisel sağlık faaliyetlerine ilişkin bilgi vermek, kişisel sağlık konularına ilişkin eyleme geçmeye teşvik etmek ve "diğer" kategorisidir.

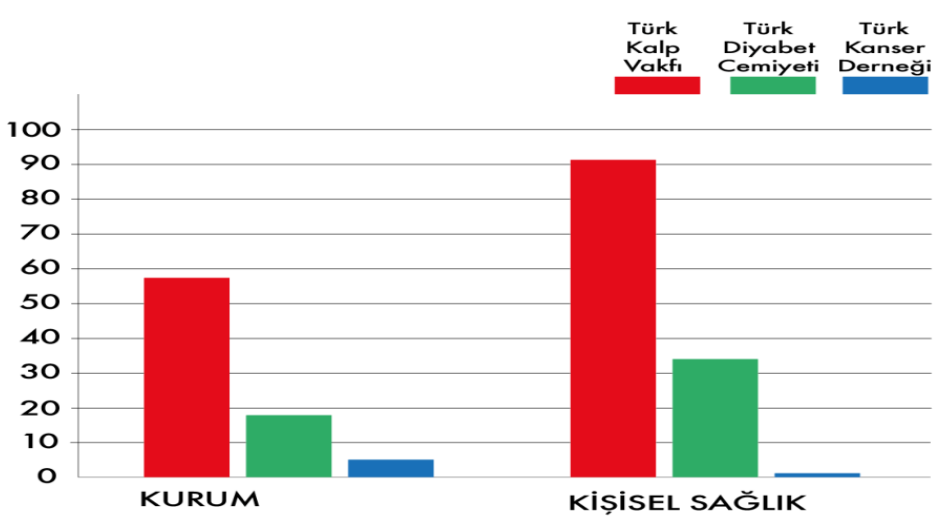

Şekil 1. Sivil Toplum Kuruluşlarının Paylaşımlarının Kişisel Sağlık ve Kuruluşla İlişkili Paylaşımları

Sivil toplum kuruluşlarının paylaştıkları içeriklerin büyük çoğunluğunun kişisel sağlıkla ilişkili (\%22.5, n:126) paylaşımlar olduğu görülmektedir. Kurum ile ilişkili paylaşımların ise kişisel sağlık bilgilerine oranla daha az olduğu görülmektedir (\%16.1, n:79). Kurumlar arası bir karşılaştırma yapıldığında Türk Kalp Vakfı \%26, Türk Diyabet Cemiyeti \%31.5, Türk Kanser Derneği \%10 oranında kişisel sağlık konularına ilişkin paylaşımlarda bulunurken, aynı kuruluşların kendi organizasyonlarına ilişkin paylaşımlarının oranı Türk Kalp Vakfı'nda \%11, Türk Diyabet Cemiyeti'nde \%10.5, Türk Kanser Derneği'nde \%26.6'dır. Bu sonuçlara göre Türk Kanser Derneği'nin organizasyona ilişkin konulara daha ağırlık verdiği görülmektedir.

Tablo 11. Sivil Toplum Kuruluşlarının Paylaştıkları Tweet'lerin Konu ve Mesaj İşlevleri

\begin{tabular}{|c|c|c|c|c|}
\hline Konu & Kalp & Diyabet & Kanser & Toplam \\
\hline $\begin{array}{l}\text { Kurum: Bilgi } \\
\text { Kurumun faaliyetlerine ilişkin bilgi verme }\end{array}$ & $23(13.1 \%)$ & $7(13 \%)$ & $0(0 \%)$ & $30(12.8 \%)$ \\
\hline $\begin{array}{l}\text { Kurum: Topluluk } \\
\text { Takipçilerle iletişim }\end{array}$ & $14(8 \%)$ & $1(1.9 \%)$ & $1(20 \%)$ & $16(6.8 \%)$ \\
\hline $\begin{array}{l}\text { Kurum: Eylem } \\
\text { Kurumun faaliyetlerine katılmaya teşvik } \\
\text { etmek }\end{array}$ & $21(12 \%)$ & $9(16.7 \%)$ & $3(60 \%)$ & $33(14.1 \%)$ \\
\hline $\begin{array}{l}\text { Kişisel sağllk: Bilgi } \\
\text { Kişisel Sağlık konularına ilişkin bilgi verme }\end{array}$ & $73(41.7 \%)$ & $25(46.3 \%)$ & $1(20 \%)$ & $99(42.3 \%)$ \\
\hline $\begin{array}{l}\text { Kişisel Sağllk: Eylem } \\
\text { Kişisel Sağllk konularına ilişkin eyleme } \\
\text { geçmeye teşvik etmek }\end{array}$ & $18(10.3 \%)$ & $9(16.7 \%)$ & $0(0 \%)$ & $27(11.5 \%)$ \\
\hline Diğer & $26(14.9 \%)$ & $3(5.6 \%)$ & $0(0 \%)$ & $29(12.4 \%)$ \\
\hline
\end{tabular}

Çalışma sivil toplum kuruluşlarının mesaj fonksiyonlarına ilişkin bir değerlendirmeyi de içermektedir. Tweet konuları iki temel kategoriye (kurumsal ve kişisel sağlık), mesaj fonksiyonları ise bilgi, topluluk ve eylem olmak üzere üç kategoriye ayrılarak değerlendirilmiştir. Bu çerçevede Türk Kalp Vakfı, \%13.1 oranında kuruluşun hizmetleri, eğitim programları veya etkinlikleri hakkında bilgilendirmeyi amaçlayan, \%8 oranında takipçilerini tanıma ve teşekkür etme ya da diğer kullanıcıların sorularına veya yorumlarına 
cevabı içeren topluluğu güçlendirmeyi amaçlayan, \%21 oranında da diğer kullanıcıları geri bildirimde bulunmaya veya kurumun faaliyetlerine aktif olarak katılmaya ve eyleme geçmelerini sağlamayı hedefleyen paylaşımlarda bulunmuştur. Türk Diyabet Cemiyeti'nde ise bu oranlar sirasiyla kurum/bilgi \%13, kurum/topluluk \%1.9, kurum/eylem \%16.7 şeklindedir. Türk Kanser Derneği'nde ise kuruluşla ilişkili tweet'lere ilişkin en fazla paylaşım kurum/eylem kategorisinde görülmektedir. Bu sonuçlara göre sivil toplum kuruluşlarının organizasyonlarına ilişkin paylaşımlarda en yüksek oranda mesaj fonksiyonlarından kuruluş adına eyleme geçirme (\%14.1) hedeflendiği anlaşılmaktadır. Kişisel sağlık ile ilişkili bir değerlendirme yapıldığında araştırmaya dahil edilen tüm sivil toplum kuruluşlarının genel halk sağlığı (örneğin, sağlık önerileri ve önleyici tedbirler) ve insanları sağlık riskleri hakkında bilgilendirmeyi amaçlayan (\%42.3) paylaşımlarda bulunduğu görülmektedir. Bu oran Türk Kalp Vakfi'nda \%41.7, Türk Diyabet Cemiyeti'nde \%46.3, Türk Kanser Derneği'nde ise \%20 şeklindedir. İnsanları koruyucu sağlık taraması almaya, yaşam tarzlarını değiştirmeye veya sağlık davranışlarını sürdürmeye teşvik etmek ve sağlık sorunlarına ilişkin daha fazla bilgi edinmek için eyleme geçmelerini hedefleyen paylaşımlara Türk kalp Vakfı ve Türk Diyabet Cemiyeti'nde rastlanmaktadır. Türk Kalp Vakfı \%10.3, Türk Diyabet Cemiyeti \%16.7 oranında bireyleri sağlık ile ilgili sorunlara karşı eyleme geçirmeyi hedefleyen paylaşımlarda bulunurken, Türk Kanser Derneği bu mesaj fonksiyonunu gerçekleştirecek hiçbir paylaşımda bulunmamıştır.

\section{Tartışma, Sonuç ve Öneriler}

$\mathrm{Bu}$ çalışma, kar amacı gütmeyen ve sağlık alanında faaliyet gösteren üç sivil toplum kuruluşunun sosyal medya araçlarından biri olan Twitter'ı sağlık iletişimi çerçevesinde nasıl kullandıkları hakkında bir fikir vermektedir. Araştırma, Türk Kanser Derneği, Türk Kalp Vakfı ve Türk Diyabet Cemiyeti'nin sosyal medyayı sağlık iletişimi çerçevesinde gerçekleştirdikleri kullanım pratiğine ilişkin ortak uygulamalar ve farklılıklar konusunda bir çerçeve çizmekteyi amaçlamaktadır. Sosyal medya ortamları, kullanıcılarına sağladığı etkileşimli iletişim olanakları nedeniyle, hedef kitleleriyle iletişim kurmak isteyen kurum ve kuruluşlara büyük olanaklar sağlamaktadır. Ancak bu yeni iletişim ortamları kullanıcılarına sunduğu iletişim olanakları çerçevesinde etkili bir iletişimi garantileyemez. Etkileşimli iletişimin sağlanabilmesi o ortamın nasıl kullanıldığıyla da doğrudan ilişkilidir. Bu çerçevede bir değerlendirme yapıldığında, çalışmaya dahil edilen sivil toplum kuruluşlarının etkileşimli iletişime olanak veren bu platformu aktif ve etkin bir şekilde kullanamadıkları görülmektedir. Twitter' da etkileşim kurmanın en önemli aracı olan "retweet" ve "mention" kullanımının sivil toplum kuruluşları tarafından çok sınırlı olarak kullanıldığı göz önüne alındığında, bu kullanım biçiminin tıpkı geleneksel medyada olduğu gibi tek yönlü bir iletişim süreci çerçevesinde gerçekleştiğini söylemek mümkündür.

Çalışma kapsamında incelenen sivil toplum kuruluşlarının Twitter'ı kullanma pratikleri değerlendirildiğinde, Twitter'ın kullanıcılarına sunduğu iletişim biçimlerine uygun kullanımın söz konusu olduğu gözlemlenmektedir. Kuruluşların, içeriklerini “\#konuetiketi” olarak tanımlanan hashtag'ler yoluyla paylaşmaları, oluşturulan içeriğin takipçilerin dışında o konu etiketini Twitter'da arayan başka kullanıcılara ulaşmasını, yaygınlaşmasını sağlayan bir araç olması nedeniyle önemli bulunmaktadır. Öte yandan sivil toplum kuruluşları tarafından oluşturulan içeriklerin fotoğraf gibi görsel malzemeyle desteklenerek paylaşılması, mesajın inandırıcılığını ve anlaşılırlığını güçlendirmeyi sağlayan bir kullanım olarak değerlendirilmektedir. 
Sivil toplum kuruluşlarının paylaştıkları tweet'lerin konuları ve mesaj fonksiyonları çerçevesinde bir değerlendirme yapıldığında, kuruluşların sağlık iletişimi çerçevesinde sosyal medya kullanım pratiklerine ilişkin ortak uygulamalar ve farklılıklar öne çıkmaktadır. Türk Kalp Vakfı ve Türk Diyabet Cemiyeti'nin Twitter kullanımının, insan odaklı ve kişisel sağlık bilgilerinin yer aldığı içeriklerden oluştuğu gözlemlenmektedir. Bu içeriklerin fonksiyonuna bakıldığında daha çok bilgi vermeyi hedefleyen paylaşımlar olduğu görülmektedir. Bu çerçevede paylaşılan tweet sayısı, Twitter özelliklerinin aktif olarak kullanımı, diğer kuruluşlara göre çevrimiçi topluluk oluşturma girişimleri ve bunun yanında insan odaklı tweet'leri, Türk Kalp Vakfı'nın Twitter kullanımının güçlü yönlerini oluşturmaktadır. Twitter'da diğer kullanıcılarla etkileşim ve diyaloğun temel araçları olan "retweet" ve "mention" kullanımının düşük düzeyde olması Türk Kalp Vakfı'nın zayıf yönü olarak değerlendirilebilir. Paylaşılan içeriklerin daha fazla kullanıcıya erişmesini sağlayan hashtag (konu etiketi) kullanımı, içeriklerde fotoğraf kullanımı, insan odaklı ve kişisel sağlık konularına ilişkin bilgi mesajlarının paylaşımı Türk Diyabet Cemiyeti'nin güçlü yönleriyken, Twitter'ın etkileşimli iletişim olanaklarının kullanılmaması ve çevrimiçi topluluk oluşturma amacıyla içerik oluşturulmaması zayıf yönleri olarak değerlendirilebilir. Türk Kanser Derneği'nin ise Twitter' 1 kullanımına ilişkin böyle bir değerlendirme yapmak mümkün görünmemektedir. Türk Kanser Derneği gerek tweet sayısı, Twitter özelliklerinin kullanımı, gerekse paylaşılan içeriklerin konuları (çevrimiçi topluluk veya insan odaklı) ve fonksiyonları anlaminda bu platformu aktif bir şekilde kullanmadığı tespit edilmiştir. Schiavo (2007)'nun sağlık iletişimine ilişkin yaklaşımı çerçevesinde kuruluşlar değerlendirildiğinde, Türk Kalp Vakfı ve Türk Diyabet Cemiyeti, să̆glık konularına ilişkin bilgilendirmede, bireyleri, kuruluşları ve kitleleri etkilemede, harekete geçirmede ve davranışları değiştirmek amacıyla Twitter' etkin kullanmışlardır. Ancak araştırmada incelenen üç kuruluş, sağlık iletişiminin temel niteliklerinden biri olan çift yönlü iletişim ve etkileşime dayanan bir ortaklık ve katılım sürecini Twitter üzerinden oluşturamamışlardır.

Sonuç olarak yapılan araştırmada Twitter'ın paydaşlarla diyaloğu ve etkileşimi teşvik etme potansiyeline rağmen, bu işlevin sivil toplum kuruluşları tarafından mütevazı bir şekilde kullanıldığı görülmüştür. Bu üç kuruluşun Twitter kullanımı, diğer sağlık kuruluşlarına genelleştirilemese de, bu sonuçlar, ele alınan kuruluşların büyüklüğü ve önemi, ulusal sağlık kuruluşlarındaki eğilimler ve sosyal medya stratejilerinin yönü hakkında güçlü gözlemler yapılmasına izin vermektedir. Sosyal medya kullanımını tek yönlü iletişim ile sınırlamak takipçiler açısından etkileşimli kapasitesini azaltan bir unsurdur. Bu çerçevede takipçilerle iki yönlü ve etkileşime dayanarak kurulan iletişim, sosyal medyanın temel amacıyken, kullanımının da bu yönde olması gerektiği düşünülmektedir. Gelecekteki çalışmalar, sağlık hizmetlerinde Twitter'ın kullanımını daha iyi anlamak için boyut ve odak bakımından daha fazla kuruluşu incelemelidir. Mesaj etkinliği üzerinde daha fazla durularak, bireylerin sağlık kuruluşlarından gelen bilginin yararına ilişkin algıları ve iletişimde bulunma istekleri bu çalışmalarda ele alınabilir.

\section{Bilgilendirme}

Bu çalışma, 7-8 Kasım 2019 tarihinde Eskişehir Anadolu Üniversitesi İletişim Bilimleri Fakültesi tarafından düzenlenen 5. Sağlık İletişimi Sempozyumu'nda sözlü bildiri olarak sunulmuştur. 


\section{Kaynakça}

Andsager, J., \& Powers, A. (1999). Social or ecomonic concerns: How news and women's magazines framed breast cancer in the 1990s. Journalism \& Mass Communication Quarterly, 76 (3), 531-550. Retrieved from https://journals.sagepub.com/doi/pdf/10.1177/.

Atabek, Ü., Atabek, G., \& Bilge, D. (2013). Televizyon sağlık programlarında ideolojik söylemler. Galatasaray Üniversitesi İletişim Fakültesi Dergisi, 3, 11-30. Retrieved from http://iletisimdergisi.gsu.edu.tr/tr/download/article-file/82913.

Atkinson, N. Saperstein, S., \& Pleis, J. (2009). Using the internet for health-related activities findings from a national probability sample. Journal of Medical Internet Research, 11(1):e4. DOI: 10.2196/jmir.1129

Bottorf, J, L., Struik, L., L., Bissell, Laura J.L., Graham, R., Stevens, J., \& Richardson, C.,G. (2014). A social media approach to inform youth about breast cancer and smoking: an exploratory descriptive study. Collegian, 21(2), 159-168. DOI: 10.1016/j.colegn.2014.04.002

Centers for Disease Control and Prevention (CDC). What is health communication. https://www.cdc.gov/healthcommunication/healthbasics/WhatIsHC.html\#What. Erişim Tarihi: 23.09.2019.

CDC, Centers for Disease Control and Prevention (2011). The health communicator's social media toolkit. https://www.cdc.gov/healthcommunication/toolstemplates/. Erişim Tarihi: 02.10.2019.

Conover, M.D., Gonçalves, B., Flammini, A., \& Menczer, F. (2012). Partisan asymmetries in online political activity. EPJ Data Science, 1(6), 1-19. DOI: $\underline{10.1140 / \text { epjds6 }}$

Çınarlı, İ. (2008). Sağlık İletişimi ve Medya. Ankara: Nobel Yayın Dağıtım.

Duffy, M. E., \& Thorson, E. (2009). Emerging trends in the new media landscape, J.C. Parkers ve E. Thorson (Ed.) Health communication in the new media landscape içinde (s. 93-116), New York: Springer Publishing Company.

Eryılmaz, A. (2011). Ergen öznel iyi oluşu ile olumlu gelecek beklentisi arasındaki ilişkinin incelenmesi. Düşünen Adam Psikiyatri ve Nörolojik Bilimler Dergisi, 24, 209-215. DOI: 10.5350/DAJPN2011240306

Fiske, J. (1997). İletişim Çalışmalarına Giriş, Çev. Süleyman İrvan, Ankara: Bilim Sanat YayınlarıArk.

Hülür, A. B. (2015). Yeni medyada sağlık söylemi üzerine bir analiz. Sosyal Bilimler Araştırma Derneği , 25, 17 - 42. DOI: 10.18026/cbusos.87810

Işık, T. (2019). Sağlık iletişiminde dijital iletişim kanallarının kullanımı: Sektör aktörlerinden Acıbadem Hastanesi'nin dijital iletişim kanalı ve sosyal medya hesaplarının incelenmesi. Cumhuriyet Illetişim Dergisi, 2, 147-162. Retrieved from https://dergipark.org.tr/tr/download/article-file/742091

Java, A., Song, X., Finin, T., \& Tseng, B. (2007). Why we Twitter: understanding microblogging usage and communities. Paper presented at the 9th WebKDD and 1st SNA-KDD 2007 workshop on Web mining and social network analysis, 56-65. Retrieved from https://ebiquity.umbc.edu/ file directory/papers/369.pdf. 
Kara, T. (2017). Instagramın sağlık iletişimi bağlamında kullanımı. Glaobal Media Journal TR Edition, 7(14), 8-22. Retrieved from http://globalmediajournaltr.yeditepe.edu.tr/sites/default/files/

Kaya, A., Yüksel, E., \& Öğüt, P. (2011). Sağlık haberlerinde 'mucize tedavi'ler. Selçuk Üniversitesi İletişim Fakültesi Dergisi, 7(1), 49-64. Retrieved from http://www.acarindex.com/dosyalar/makale/acarindex-1423911799.pdf

Kayabalı, K. (2011). İnternet ve sosyal medya evreninde sağlık. İyi Klinik Uygulamalar Dergisi (IKU), 25, 14-20. Retrieved from https://iyiklinikuygulamalar.com/wpcontent/uploads/2020/04/Say\%C4\%B1-25-\%C4\%B0nternet-ve-Sosyal-Medya-EvrenindeSa\%C4\%9Fl\%C4\%B1k.pdf

Kent, M., Taylor, M., \& White, W.J. (2003), The relationship between web site design and organizational responsiveness to stakeholders. Public Relations Review, 29(1), 63-77. DOI: $\underline{10.1016 / S 0363-8111(02) 00194-7}$

Kreps, G.,L., Bonaguro, E., W., \& Query, L. (1998). The history and development of the field of health communication, L.D. Jackson ve B.K. Duffy (Eds.). Health communication research: guide to developments and directions içinde (s.1-15), Westport, CT: Greenwood Press.

Korda, H., \& Itani, Z. (2013). Harnessing social media for health promotion and behavior change. Health Promotion Practice, January, 15-23. DOI: 10.1177/1524839911405850

Krippendorff, K. (2004). Content analysis an introduction to its methodology. Thousand Oaks: Sage Publications.

Lee, J., \& Xu, W. (2018). The more attacks, the more retweets: Trump's and Clinton's agenda setting on Twitter. Public Relations Review, 44, 201-213. DOI:10.1016/j.pubrev.2017.10.002

Lilleker, D. G. (2013). Siyasal iletişim temel kavramlar. Y. Devran, A. Nas, B. Eksi ve Y. Göksun (Ed), İstanbul: Kaknüs Yayınları.

Lovejoy, K., \& Saxton, G.D. (2012). Information, community, and action: how nonprofit organizations use social media. Journal of Computer-Mediated Communication, 17, 337-353. DOI: 10.1111/j.1083-6101.2012.01576.x

Mendi, B. (2015). Sağlık iletişiminde sosyal medyanın kullanımı: Dünyadaki ve Türkiye'deki uygulamalar. Marmara Üniversitesi Öneri Dergisi, 11(44), Temmuz, 275-290. DOI: 10.14783/od.v11i44.5000080015

Moorhead, S., A., Hazlett, D.E., Harrison, L., Carroll, J. K., Irwin, A., \& Hoving, C. (2013). A new dimension of health care: systematic review of the uses, benefits, and limitations of social media for health communication. Journal of Medical Internet Research, 15(4). DOI:10.2196/jmir.1933

Neiger, B., Thackeray, R., Burton, S. H, Thackary, C.R., \& Reese, J. (2013). Use of Twitter among local health departments: an analysis of information sharing, engagement, and action. Journal of Medical Internet Research, 15 (8). DOI:10.2196/jmir.2775

Neuendorf, K. A. (2002). The content analysis guidebook. Thousand Oaks: Sage Publications.

Okay, A. (2009). Să̆glı iletişimi. İstanbul: MediaCat Kitapları. 
Park, H., \& Reber, B. H. (2010). Using public relations to promote health: a framing analysis of public relations strategies among health associations. Journal of Health Communication, 15, 39-54. DOI:10.1080/10810730903460534

Parker, J.C., \& Thorson, E. (2009). Health communication in the new media landscape. New York: Springer Publishing Company.

Robledo, D. (2012). Integrative use of social media in health communication. Online Journal of Communication and Media Technologies, 2(4), 77-95. Retrieved from https://s3.amazonaws.com/academia.edu.documents/30875344/245.pdf

Saxton, G. D., Guo, S. C., \& Brown, W. A. (2007). New dimensions of nonprofit responsiveness: the application and promise of internet-based technologies. Public Performance $\mathcal{E}$ Management Review, 31(2), 144-173. DOI:10.2753/PMR1530-9576310201

Schiavo, R. (2007). Health communication from theory to practice. San Francisco: Jossey-Bass.

Pew Research Center (2009). The social life of health information. https://www.pewinternet.org/2009/06/11/the-social-life-of-health-information/, Erişim Tarihi 01.10.2019.

Rybalko, S., \& Seltzer, T. (2010). Dialogic communication in 140 characters or less: how fortune 500 companies engage stakeholders using Twitter. Public Relations Review, 36, 336-341. DOI: 10.1016/j.pubrev.2010.08.004

Sezgin, D. (2010). Sağlık iletişimi paradigmaları ve Türkiye: medyada să̆lık haberlerinin analizi, (Doktora tezi, Ankara Üniversitesi, Ankara). Erişim adresi: http://tez2.yok.gov.tr/

Tabak, R. S. (2003). Sağlık İ-iletişimi. İstanbul: Literatür Yayınları.

Thackarey, R., Neiger, B.L. \& Keller, H. (2012). Integrating social media and social marketing: a four-step process. Health Promotion Practice, 13(2), 165-168. DOI: $10.1177 / 1524839911432009$

Thomas, R.K. (2006). Health communication. New York: Springer.

Türk Diyabet Cemiyeti, http://www.diabetcemiyeti.org/c/vizyonumuz-ve-misyonumuz). Erişim tarihi: 10.09.2019

Türk Kanser Deneği, (http://www.turkkanserdernegi.org/tr/hakkimizda.html, Erişim tarihi: 10.09.2019

Türk Kalp Vakfı, https://tkv.org.tr/kurumsal/hakkimizda). Erişim tarihi: 10.09.2019

We Are Social ve Hootsuitte (2018). 2018 Global Digital Raporu. https://wearesocial.com/blog/2018/01/global-digital-report-2018. Erişim tarihi: 11.07.2018.

Yüksel, E., Koçak, A., Kaya, A.Y., \& Aydın, S. (2014). Check up aağlık iletişimi kaynak, ileti ve hedef kitle bağlamında sağlık konulu yayınların analizi. Konya: LiteraTürk Academia. 